\title{
Optimization of The Use of Togaf Adm in The Design of Information Systems For Islamic Boarding Schools
}

\author{
Nurliana Nasution ${ }^{1}$, Mhd Arief Hasan ${ }^{2}$ \\ ${ }^{1,2}$ Informatic Engineering Study Program, Universitas Lancang Kuning, Pekanbaru \\ email : ${ }^{1}$ nurliananst@unilak.ac.id, ${ }^{2}$ m.arif@unilak.ac.id
}

\begin{abstract}
Article Info
Article history:

Received 11 25, 2021

Revised 12 10, 2021

Accepted 12 20, 2021

\section{Keywords:}

Framework

Information System

Islamic Boarding School

Pesantren

TOGAF

ABSTRACT

Pesantren is an educational institution that stands traditionally where students live in one place to live with each other and study under the guidance of a teacher who is also known as a Kiai. For its implementation, many things must be managed by a boarding school, starting from student registration, student placement, student learning, and evaluation of student learning at the boarding school. So far, there is no adequate system for all of these administrative needs. The purpose of this study is to build an information system framework for Islamic boarding schools using the TOGAF FRAMEWORK. Miftahul Huda Islamic Boarding School Pekanbaru City uses the TOGAF-ADM methodology as the standard tool used. The use of TOGAF can bring a consistent enterprise architecture, based on stakeholder requirements, and bring some considerations. . In designing this blueprint, it will rely on the work steps of the TOGAF ADM Framework, in which this enterprise architecture framework is divided into (four) categories, namely: business architecture, data, applications, and technology.
\end{abstract}

This is an open access article under the CC BY-SA license.

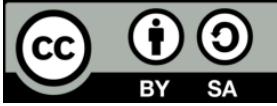

\section{Corresponding Author:}

Nurliana Nasution

Informatic Engineering Study Program

Universitas Lancang Kuning

Pekanbaru, Indonesia

Email: nurliananst@unilak.ac.id

(C) The Author(s) 2021

\section{Introduction}

Information processing has an important role in an institution, including in education, business and government institutions. Information processing strategies and techniques influence the processing results and management decisions taken based on these results. The development of modern technology has allowed information processing to be carried out with the help of computers. In general, with the processing of data with computers the faster and more accurate information is generated. Speed and accuracy are very helpful in getting information quickly and accurately which in turn helps management make decisions regularly quickly and effectively.

Pesantren is an educational institution that stands traditionally where students live in one place to live with each other and study under the guidance of a teacher who is also referred to as a Kiai. Then stay in a hostel for a set period. The student is in the mosque complex. In addition to studying, his daily activities are used for worship, the Koran, and other religious activities. Santri lives in a complex environment together and is filled with rules that restrict them from going in and out of the Islamic boarding school. According to the term, Pondok language means a place to live made of bamboo. And students are students who take part in educational 
activities. For its implementation, many things must be managed by a boarding school, starting from student registration, student placement, student learning, and evaluation of student learning at the boarding school. So far, there is no adequate system for administrative needs. The purpose of this research is to build an information system framework for Islamic boarding schools to facilitate the world of Islamic boarding schools in managing more systematic and comprehensive management of boarding school administration to create a more modern education domain governance and information technology for Islamic boarding schools. And another is to invite the pesantren community to be able to apply the togaf framework as a tool for their information technology development. There are several frameworks that you can use to develop enterprise architecture. One of these frameworks is TOGAF. TOGAF is a framework for enterprise architecture. TOGAF allows assisting companies in building a framework in the hiring process, production process, company performance, and maintenance of company architecture. One of its advantages is TOGAF's flexibility to collaborate with other frameworks. Enterprise architecture development using TOGAF is carried out iteratively based on its function in each element. This method is also known as TOGAF Architecture Development Method (ADM)[1].

Information systems are the cornerstone of modern organizations. They not only support business processes but can also provide strategic advantages[1]. The Open Group Architecture Framework (TOGAF) is an enterprise architecture framework that is suitable for use by many companies or institutions that have not used the Framework for designing their systems. The TOGAF framework has eight phases in the form of a cycle. Some of these phases include architecture vision, business architecture, information system architecture, technology architecture, opportunities and solutions, migration planning, implementation governance, and architecture change management [2].

We researched at an Islamic boarding school in Pekanbaru City, Riau Province, Indonesia. The boarding school is called Miftahul Huda Islamic Boarding School. This Islamic Boarding School is under the auspices of an Organizational Institution called the Regional Leadership Council of the Lembaga Dakwah Islam Indonesia (LDII) Riau Province. The design of the enterprise architecture is carried out to support the information system business processes of Islamic boarding schools. In this research, we use TOGAF ADM to assist in designing the framework in Islamic boarding schools. We chose Togaf ADM because it is a generic method in its implementation and flexible in quantifying various modeling techniques in designing according to the needs and characteristics of Islamic boarding schools. This study aims to develop a roadmap in architectural vision and business architecture, a targeted business architecture for the executive management of organizations[2] [3]. The technology architecture in ADM provides an overview of the organization's IT infrastructure in a pesantren environment.

\section{Literature Review}

Enterprise Architect TOGAF is a framework developed by the Open Group from 1995 until now. In addition, TOGAF is a model that can represent certain subjects that are made simpler. This can be seen from the elaboration of the point of view and the focus of management's attention on the organizational needs identified in the preliminary phase. TOGAF was chosen because of its completeness and very detailed guidance in translating the ideal architectural form and choice of information technology to run existing business processes. The general flow of TOGAF ADM is as follows:

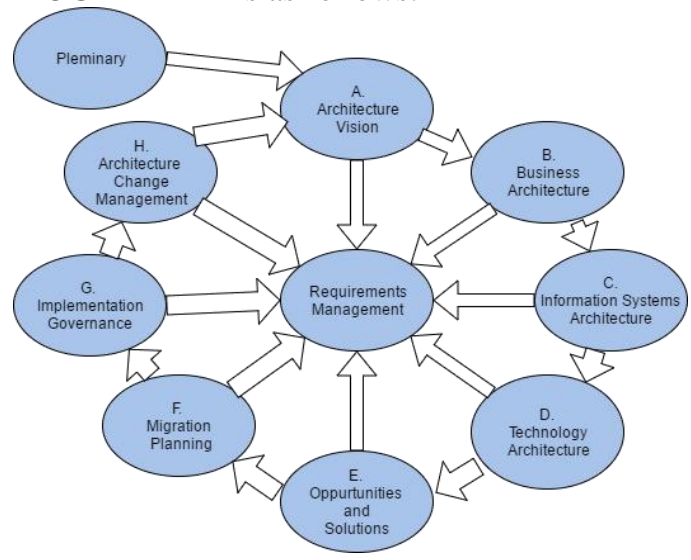

Figure 1. Togaf ADMOGAF ADM

[3] 
TOGAF has its view, which can be defined as "a formal description of a system, or a detailed plan of a system at the component level to guide its implementation", or as "the structure of components, their interrelationships, and the principles and guidelines that govern their design and evolution from time to time"[4]

The use of TOGAF can bring a consistent enterprise architecture, based on stakeholder requirements, and bring some considerations. This will bring the needs of stakeholders. TOGAF plays an important role in reducing and reducing risk in developing architecture. TOGAF has a framework that can provide value and enable users to develop open systems and based solutions to address business problems and enterprise needs[5].

The stages in TOGAF ADM are used to design information strategic planning for Islamic Boarding Schools. The following explanation of the stages in TOGAF ADM:

- Preliminary phase: this stage is to determine how to prepare to achieve organizational goals.

- Architecture Vision: It is the architectural development phase that includes the preparation of the architectural vision, identifying the stakeholders to start the development of the architecture.

- Business Architecture: includes the development of a business architecture to support the architectural vision, to build models using UML (Unified Modeling Language) tools.

- Information System Architecture: Emphasis on information systems which include data architecture and application architecture, data is used for business needs. It should be noted that the first step to implementing TOGAF ADM is to define preparation and strategy by identifying the context of the architecture to be developed and determining the part of the architecture to be designed. Starting from the business architecture, information systems architecture, technology architecture, then define the architectural capabilities to be designed and developed.

\section{Research Methodology}

In this study, to design the Information System Framework at Islamic Boarding Schools, it refers to the TOGAF (The Open Group Architecture Framework) framework[6][7][8]. Togaf is an Architecture that provides a method for classifying solution architectures and artifacts as they evolve from a generic Basic Architecture to an Organization Specific Architecture[9][10][11]. The TOGAF framework is used as an architectural framework that provides a comprehensive approach to the design, planning, implementation, and governance of information system architecture that will be implemented later at Miftahul Huda Islamic Boarding School. The stages of research are carried out so that research can run systematically and then be compiled into a research flow chart. The following is the research flow in designing the Miftahul Huda Islamic Boarding School Information System Framework using Togaf ADM.

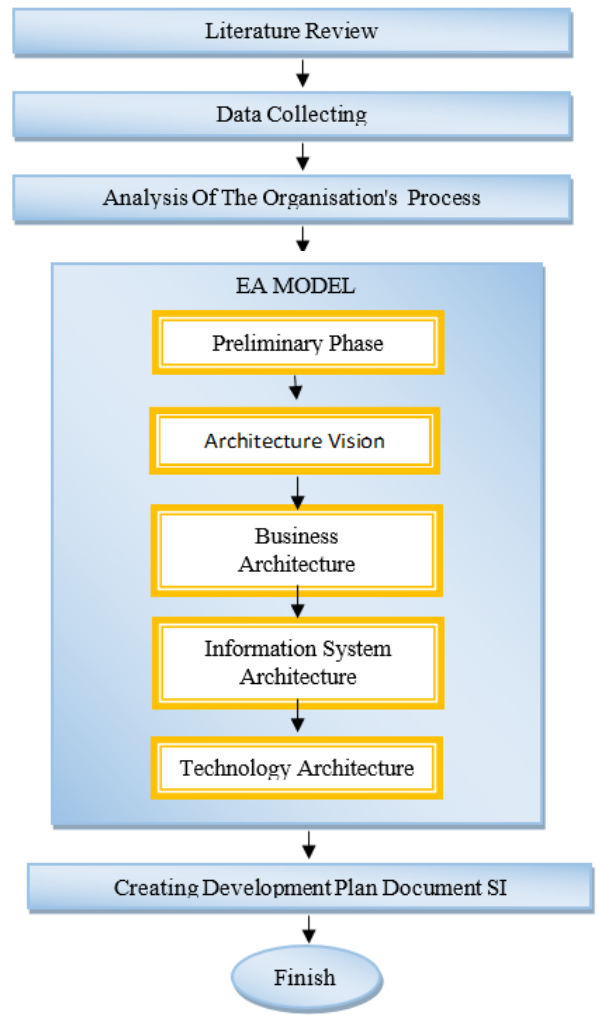

Figure 2. Flowchart Sistem 
Based on the research stage, Figure 2 describes an overview of the system to be built in the information system and describes the interaction with the functions in the system to be built at Miftahul Huda Islamic Boarding School, Pekanbaru City.

\section{Results and Discussion}

After a direct visit to the Miftahul Huda Islamic Boarding School was conducted, it was found that the Miftahul Huda Islamic Boarding School in Pekanbaru currently does not use information systems at all in its daily activities that can provide information to students, parents of students, and the community. The current condition is that there is no good access to information systems. This results in ineffective and inefficient activities at the Islamic Boarding School. Therefore, it is necessary to design an information system that can accommodate the service needs of students and Islamic boarding schools. For this initial stage, we will examine what information systems are needed by the pesantren. We build an information system design model using the TOGAF ADM framework. The output of this research will produce a Blue Print for modeling the design of the Miftahul Huda Islamic Boarding School in Pekanbaru City. This blueprint becomes the basis for making applications in the Pondok Pesantren environment. In designing this blueprint, it will rely on the work steps of the TOGAF ADM Framework, in which this enterprise architecture framework is divided into (four) categories, namely: business architecture, data, applications, and technology. The details of each stage of the TOGAF ADM design are explained as follows:

\subsection{Preliminary Phase}

The preliminary phase is the initial phase in enterprise architecture planning, this phase aims to explain the steps in making the framework and methodology, making architectural tools, confirming the support (commitment) from the management, namely Miftahul Huda Islamic Boarding School Pekanbaru.

1. Scope of enterprise Architectural design is carried out by elevating the business processes of information systems for Teaching and Learning Activities (KBM) in Miftahul Huda Islamic Boarding School, namely the business process of accepting new students, registration business processes, business processes of processing student data, business processes of processing student grades data at the Lodge.

2. The resources (inputs) needed to develop an EA information system for Miftahul Huda Islamic Boarding School are the content, mission, main tasks and functions, organizational structure, business strategy, IT strategy, goals, objectives, business processes as well as system conditions and information technology.

3. Determine the Architectural Framework and Architectural Methodology The framework that will be used here refers to the use of the TOGAF ADM Framework.

4. Implement architectural tools or tools in enterprise architecture planning effectively and efficiently. This means that there has been a match between the problem solving carried out or the solutions provided with the organization both in terms of policies and operations

The organizational structure of an Islamic boarding school can show what activities are handled at the Islamic boarding school. So that the determination of the Organizational Structure will determine the strategic business steps of the Islamic Boarding School. Miftahul Huda Islamic Boarding School Pekanbaru is an Islamic boarding school, its business process cannot be separated from forming a cadre of students who are ready to be released as missionaries of Lembaga Dakwah Islam Indonesia (LDII) throughout Indonesia. Therefore, the main functional areas can be described as the business process mapping in Figure 3 which can generally be grouped into main activities and supporting activities.

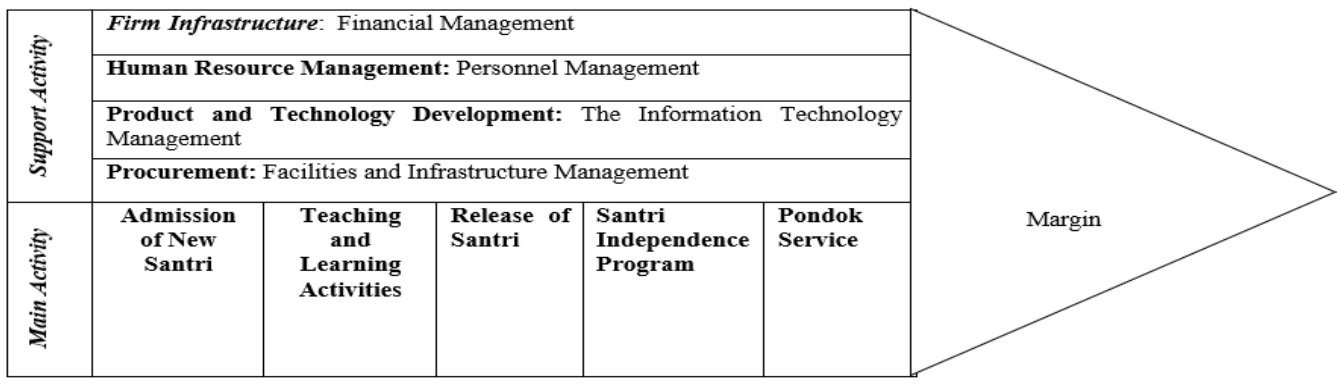

Figure 3. Proses Bisnis Mapping 
The main activity, consisting of

1. Admission of New Santri: Acceptance of Santri from Miftahul Huda Islamic Boarding School is an inseparable part of the activities of accepting students, admission selection, student category (in general, students are divided into two students with independent fees, students with scholarships from LDII branches at the sub-district and village levels), class placement student.

2. Teaching and Learning Activities: The process of teaching and learning activities where students follow the curriculum activity program provided at the lodge starting from learning the Qur'an, Hadith, Memorizing, Tajwid, Nahwu Sharif, and others. Each of these activities has its learning outcomes and assessment targets.

3. Release of Santri: The process of releasing students here is where the students have received a good standard of assessment from the Teaching and Learning Activities in the cottage. Santri are ready to be delivered to the Central LDII Islamic Boarding School in Pondok Walibarokah Burengan Kediri. To take the main test to get a diploma/legality as a preacher from the Indonesian Islamic Da'wah Institute which is ready to be released to all LDII branches at the sub-district and village levels throughout Indonesia. In this case, the process of releasing students automatically makes the students concerned registered as alumni of the Miftahul Huda Islamic Boarding School Pekanbaru.

4. Santri Independence Program: This activity program includes providing training/workshop supplies to students as a provision for them when they leave the Islamic Boarding School later. This activity program includes entrepreneurship training, da'wah management, character education, management training programs for Early childhood education programs age children, and others.

5. Pondok Service: This activity is a general service from the cottage to the wider community. Such as learning the Qur'an and Hadith Online, Sharia Law Consulting, and others.

Support activities consist of

1. Financial Management: This system is needed to regulate the financial management of Islamic Boarding Schools. Starting from finance for the operational activities of the Islamic boarding school, shodaqoh, income and expenses of other Islamic boarding schools

2. Personnel Management: This activity includes data collection of the boarding school staff (educating staff) and non-educational staff.

3. The Information Technology Management Unit for Islamic Boarding Schools includes the management of student databases, libraries, correspondence administration, and laboratories.

4. Facilities and Infrastructure Management is a unit in recording the availability of supporting equipment for activities in the cottage, inventory of goods, procurement of consumption, and others.

\subsection{Architecture Vision}

At this stage, the process of identifying the needs of the management of the Islamic Boarding School is carried out before we will design the enterprise architecture. This stage is called the Architecture Vision. This stage will identify what will be done to present several aspects, namely the vision and mission, business goals, business objectives, and stakeholders. The core business of the Miftahul Huda Islamic Boarding School in Pekanbaru City is to provide broad religious education services for the community and then graduate students who can provide solutions to various problems of Muslims. Graduates will become novice da'wah interpreters assigned to the LDII branches at the sub-district and levels. So that the implementation of teaching and learning activities for the students can be well controlled, an Information System and Information Technology are needed that can help facilitate the work of the Islamic Boarding School in managing their students.

The stakeholders who are directly related to each Islamic Boarding School activity with an enterprise architecture created at Miftahul Huda Islamic Boarding School are as follows: Boarding School Supervisory Section, Ministry of Religion, Boarding School Board, Pamong, Prospective Santri, Santri, Parents/Parents, Teachers, and alumni.

The relationship mechanism between the enterprise architecture that was built with stakeholders can be seen in Table 4.1 below:

Table 1. Mechanism of the relationship between enterprise architecture design and stakeholders

\begin{tabular}{cll}
\hline NO. & STAKEHOLDERS & RELATIONSHIP MECHANISM \\
\hline $\mathbf{1}$ & Supervisory Agency and & ASSESSMENT OF ISLAMIC BOARDING SCHOOL \\
& Ministry of Religion & ACTIVITIES \\
$\underline{\mathbf{2}}$ & Parents/guardians & ACCESS INFORMATION FOR ISLAMIC BOARDING \\
& & SCHOOLS \\
\hline
\end{tabular}




\begin{tabular}{clc}
\hline NO. & STAKEHOLDERS & RELATIONSHIP MECHANISM \\
\hline$\underline{\mathbf{3}}$ & Prospective Students & TEST AND INTERVIEW \\
$\underline{\mathbf{4}}$ & Students & PROVIDING STUDENT ADMINISTRATION SERVICES \\
$\underline{\mathbf{5}}$ & Teacher & AS A USER OF ISLAMIC BOARDING SCHOOL INTERNAL \\
$\underline{\mathbf{6}}$ & Non-Educator (Staff) & SERVICES \\
$\underline{\mathbf{z}}$ & ALUMNI & SERVICES OFE ISLAMIC BOARDING SCHOOL INTERNAL \\
\hline
\end{tabular}

\subsection{Business Architecture}

This stage describes the current organizational architecture and develops it by developing a strategy to achieve the business goals that have been set by conceptualizing an information system-based business solution based on current conditions, in the form of a diagram as shown in Figure 4.

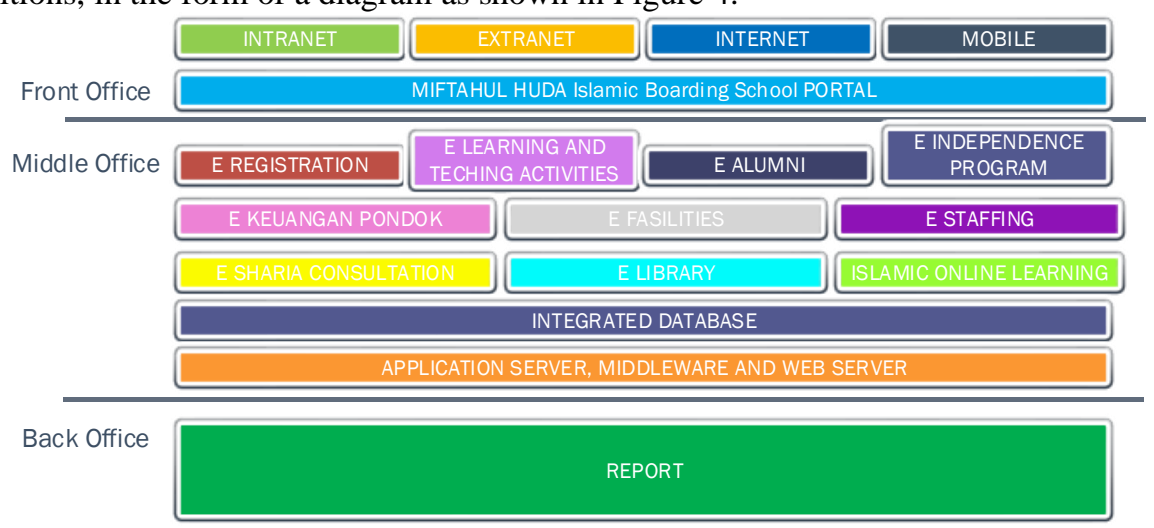

Figure 4. Diagram Value Chain

\subsection{Information System Architecture}

At this stage, the Information System Architecture modeling at Miftahul Huda Islamic Boarding School in Pekanbaru City is divided into 2 main stages, namely Data Architecture Modeling and Application Architecture Modeling. This architectural design is based on the Value Chain Diagram that has been obtained previously in Figure 4. Table 3 will later see the entities that will appear in the Information System architecture of the Miftahul Huda Islamic Boarding School. At the same time the relationship between these entities because the database that is built there is a relationship between one another.

Table 3. Relation of Business Entity List and Data Entity in Data Architecture

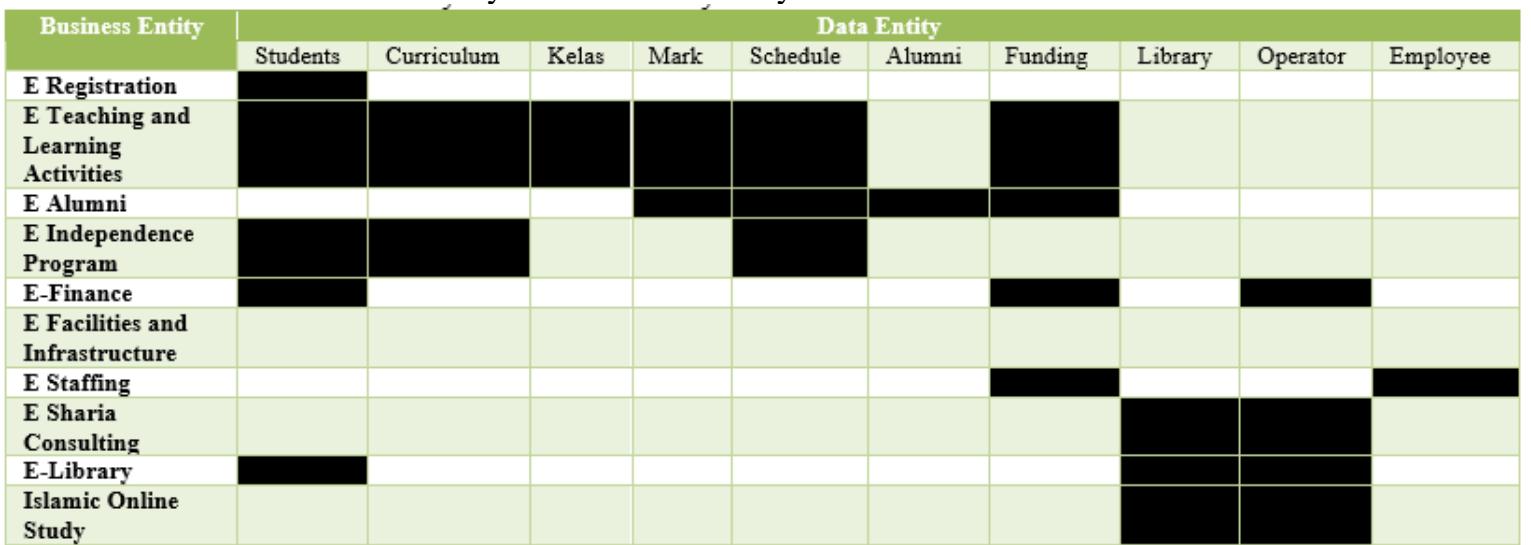

Then after the data architecture was formed, the researcher made the concept of Application Architecture. The application architecture is as follows: 


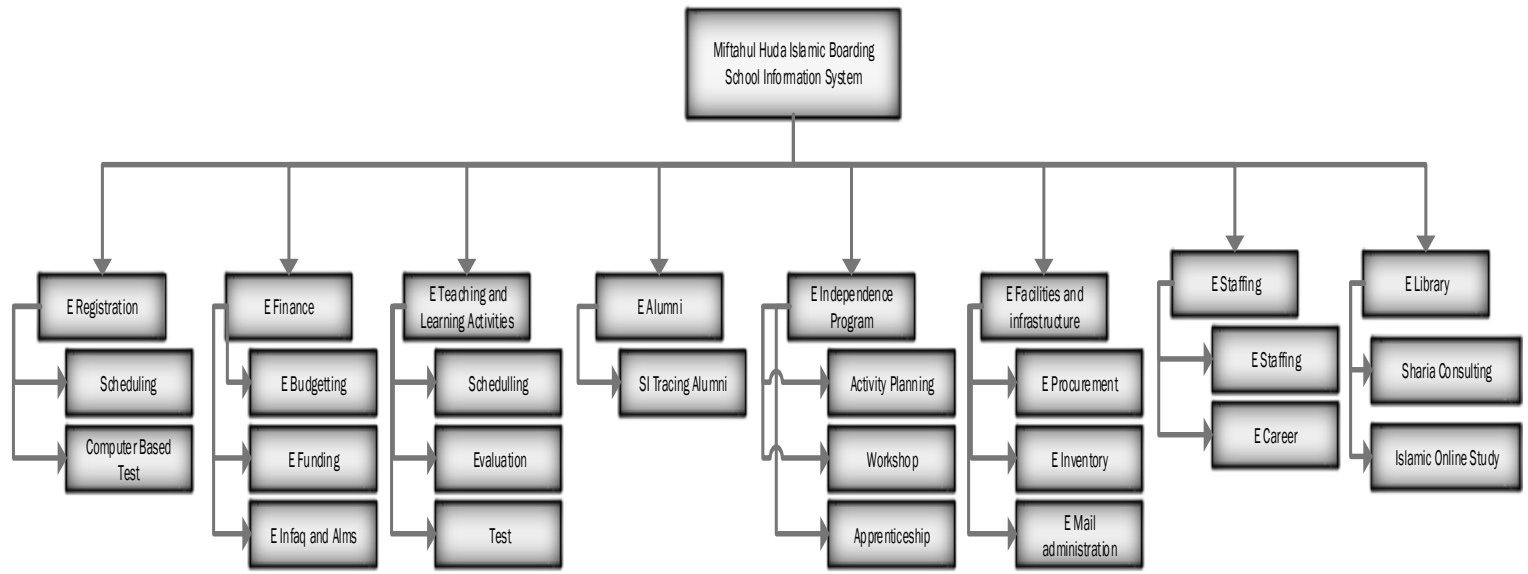

Figure 4. Application Architecture

In figure four above is the menu structure of the proposed Miftahul Huda Islamic Boarding School Information System Architecture. There are eight main menu structures of the application including $\mathrm{E}$ Registration, E-Finance, E-Teaching and Learning Activities, E Alumni, E Independence Program, E Facilities, E Staffing, and E-Library. All of the above system requirements can be made simultaneously or in stages.

\subsection{Technology Architecture}

Building an information system architecture is inseparable from the topology, configuration, and specifications of technology infrastructure in the form of hardware, system software, databases, communication devices, and networks that must be available to produce the required information system. This stage also considers the alternatives needed in selecting the technology to be used in Islamic boarding schools. The proposed technology architecture to be built is as follows.

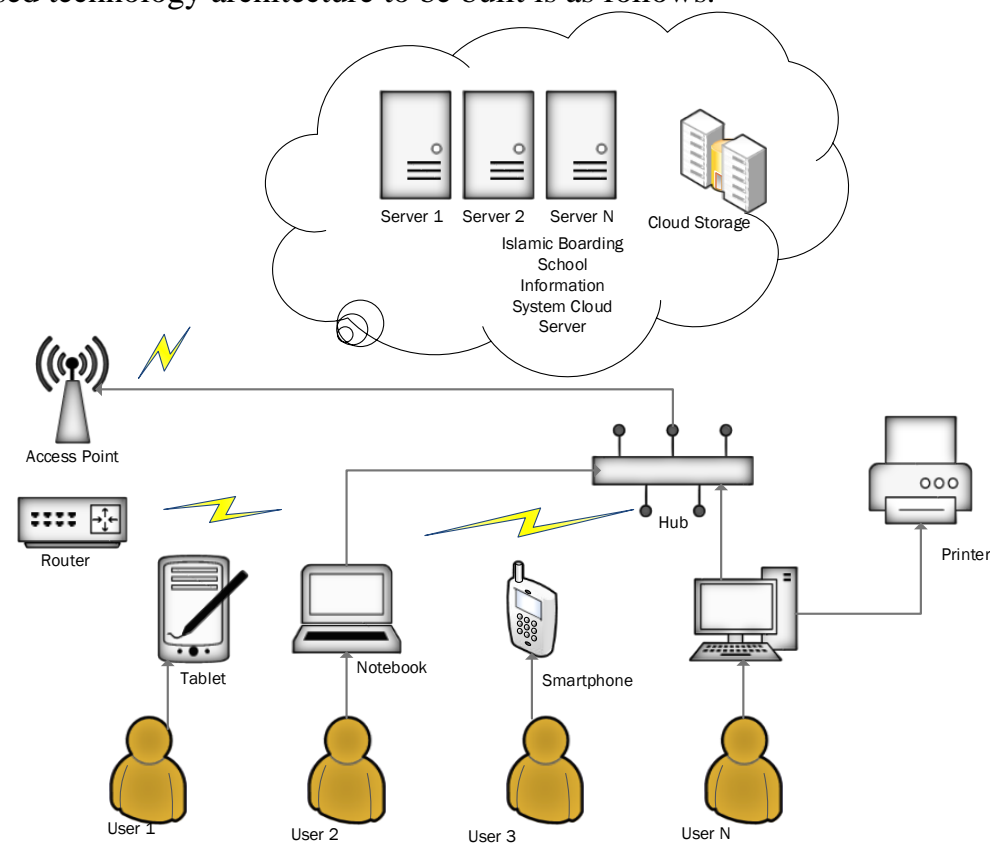

Figure 5. Network Schematic Proposal

In the picture above, the network scheme that will be proposed at the Miftahul Huda Islamic Boarding School in Pekanbaru Indonesia is described. The information system developed is already a cloud-based system. So the pesantren no longer needs to be bothered about procuring server machines. The low cost and easy maintenance are the reasons why this system should be developed based on Cloud. Then the users of this system no longer need to be bothered about the limitations of media access. They can use PCs, Smartphones, 
Notebooks, Tablets, or other devices connected to the Internet to access the Pondok Pesantren Information System.

\section{Conclusion}

Based on the results of the discussions that have been submitted according to the research stages in each chapter, it can then be concluded that the appropriate enterprise architecture design at the Miftahul Huda Islamic Boarding School in Pekanbaru City has been successfully created using the TOGAF-ADM methodology as the standard tools used.

Suggestions in the form of the need for commitment from the head of each department or organizational unit to the implementation and implementation of the information system to be built, so that the development goals of this integrated information system can run well in helping the availability of data or information that is fast, precise and accurate.

\section{Acknowledgment}

We would like to thank the Lancang Kuning University Research and Community Service Institute for funding this funding By Contract Number 372/UNILAK-08/B.07/2018. And the Miftahul Huda Islamic Boarding School in Pekanbaru City which is the place of this research

\section{References}

[1] V. Goepp and M. Petit, "Insight from a comparison of TOGAF ADM and SAM alignment processes ScienceDirect," IFAC-PapersOnLine, vol. 50, no. 1, pp. 11707-11712, 2017, doi: 10.1016/j.ifacol.2017.08.1693.

[2] J. Fahana and A. Azhari, "TOGAF for designing the enterprise architecture of LAZISMU," vol. 2, no. 2, pp. 5864, 2018.

[3] R. Harrison, "TOGAF TM 9 Foundation Study Guide," Bus. Manag., p. 243, 2009, doi: 10.1111/j.13652702.2009.02827.x.

[4] T. R. Sari and E. Rahmawati, "TOGAF ADM to Improve the Promotion of Farm Edu-Tourism in Pondok Rangon Area," vol. 3, no. 2, pp. 280-287, 2019.

[5] R. Eko and J. Fernandes, "Designing Enterprise Architecture Enable of Business Strategy and IS / IT Alignment in Manufacturing using TOGAF ADM Framework," vol. 1, no. 2, pp. 1-7, 2019.

[6] D. Minoli, Enterprise Architecture A to Z. New York, United States of America: CRC Press, 2008.

[7] D. Proenca and J. Borbinha, "Enterprise architecture: A maturity model based on TOGAF ADM," Proc. - 2017 IEEE 19th Conf. Bus. Informatics, CBI 2017, vol. 1, pp. 257-266, 2017, doi: 10.1109/CBI.2017.38.

[8] S. Buckl, A. M. Ernst, F. Matthes, R. Ramacher, and C. M. Schweda, "Using enterprise architecture management patterns to complement TOGAF," Proc. - 13th IEEE Int. Enterp. Distrib. Object Comput. Conf. EDOC 2009, pp. 34-41, 2009, doi: 10.1109/EDOC.2009.30.

[9] J. Galih, P. Negara, A. Wahju, and R. Emanuel, "Enterprise Architecture Design Strategies for UGK Using TOGAF ADM," vol. 436, pp. 491-495, 2020.

[10] I. Yosef, M. Edward, and A. Agusdian, "Proposal of TOGAF ADM Enterprise Continuum for OrganizationSpecific Solution on e-Government," no. November, pp. 283-288, 2014.

[11] U. De Fatima Gusmao and D. B. Setyohadi, "Strategic planning for the information development of IPDC (Instituto Profissional de Canossa) library using TOGAF method," 2017 5th Int. Conf. Cyber IT Serv. Manag. CITSM 2017, 2017, doi: 10.1109/CITSM.2017.8089289. 